\title{
The Macaw Biology Program: Outstanding Content, Inspired Students
}

\author{
Miller, Kenneth R. and Levine, Joseph S.: Miller and Levine Biology. New York Ed. \\ Boston: Prentice Hall, 2010 (ISBN-10: 0-13-369343-0)
}

\section{Celeste Cookie Barker}

Published online: 18 August 2011

(C) Springer Science+Business Media, LLC 2011

Our old set of Miller and Levine dragonfly biology textbooks had all the signs of well-loved books, earmarked pages, ripped corners, and weakened spines. Eventually, after increasing class enrollment, I needed to find a new textbook. The dragonfly book had gone out of print, and there were no used books to be found. As luck would have it, the 2010 edition of the Miller and Levine Biology program was just hitting the market. After perusing the website (www.biology.com) and studying the complimentary copy I had picked up at the Science Teachers Conference in Rochester, NY, I was more than convinced that this would be the perfect upgrade. The material was current, detailed, well illustrated, written in an attentioncatching style, and the online resources were very rich in content and variety. The last step, or should I say hurdle, was to get the approval of our Board of Education.

A month after submitting a copy of the macaw biology book to our BOE for adoption, the book came back to the meeting with numerous post-it-notes flagging the pages. Further discussion revealed that two BOE members were concerned with the presentation of the evolution unit. There were concerns about using radiometric dating to age fossils, the illustration of whale phylogeny indicating that the ancestors of modern whales walked on all fours, the fact that genes evolve, the very idea that evolution was being presented as fact when it is "only a theory" ... the list goes on. After lengthy discussion and written support from Niles Eldredge, Ken Miller, and Joe Levine, the BOE voted 4-1 to adopt the macaw biology textbook for use in our school.

\section{C. Barker $(\bowtie)$}

Outstanding Biology Teacher Award NABT 1999,

Biology-Chemistry Teacher, Schroon Lake Central School,

Schroon Lake, NY, USA

e-mail: cbarker@schroonschool.org
It has been one and a half years since our students have been interacting with the revised Miller and Levine Biology program, and we are reaping the benefits. In our science classroom, the students are taking more responsibility for their own learning. The number of students using technology outside the classroom to study biology has increased. And $100 \%$ of our students passed the required state exam in biology.

The quality of the biology content is outstanding. It is current and well researched. Their treatment of gene regulation is such an example. Figure 13-18 effectively shows the blocking of gene expression. Along with the clearly articulated text, the concept of RNA interference is no longer accessible to only a few. All students can now better understand cell differentiation.

A useful feature of the Miller and Levine Biology program is the framework that is used to design curriculum. Called "Understanding by Design," this framework focuses on "Big Ideas" and "Big Questions" that are carried through the chapters and units. The goal of this framework is to create deep connections to the concepts allowing knowledge to be transferrable. It is flexible and allows multiple avenues for teachers to specialize or differentiate instruction. Using the online resources, rich with interactive study tools, videos, lesson overviews, and assessments, differentiated instruction is only a mouse click away. As a teacher, I can assign each student different activities to complete either in class or on their own time. These assignments may be graded or not, depending on my preference. Each chapter video is creative and interesting as evidenced by the discussion questions it stimulates from students. All teacher resources are available on DVD, so if Internet access is limited or non-existent, the book and provided editable review sheets and labs will lead students through a comprehensive study of each chapter. 
The ExamView assessment suite that accompanies the textbook has an extensive bank of test questions that are correlated with state and national standards and a management program to allow the teacher to generate and publish exams specific to each class. The analysis of such tests gives teachers immediate feedback on items such as individual student achievement, group achievement, and item remediation. Quality, objective-based tests can be generated quickly and any re-teaching can begin immediately.
Ultimately, I chose this textbook because I felt the science was sound and the presentation was student friendly. The online resources were icing on the cake, and very delicious icing at that!

Thank you Ken Miller and Joe Levine for putting your time and effort into creating such a high-quality biology program. Personally, I would like to thank Ken Miller, Joe Levine, and Niles Eldredge for helping to defend quality science education in a small rural school in the Adirondacks. Many students will benefit from your efforts. 